Mr. G. S. Dawes, Department of Pharmacology, University of Oxford; Dr. J. L. Henderson, first assistant, Department of Child Life and Health, University of Edinburgh; Dr. R. S. Illingworth, late officer-in-charge of a medical division (Lieutenant-Colonel, R.A.M.C.); Mr. R. M. MayonWhite, Physiological Laboratory, Armoured Fighting Vehicles School, Lulworth; Dr. W. A. Law, late officer-in-charge of a surgical division (LieutenantColonel, R.A.M.C.) ; Mr. N. H. Martin, late assistant director of pathology, 21 Army Group and B.A.O.R. (Lieutenant-Colonel, R.A.M.C.) ; Dr. R. L. Richards, assistant physician, Neurovascular Unit, E.M.S. Hospital, Gogarburn, Edinburgh. Drs. Henderson and Illingworth were awarded fellowships in 1939, but were unable to take them up owing to the War.

\section{Comet Timmers (1946a)}

Positions of this comet have been recorded by several British observers, and an orbit has been computed by Dr. M. Davidson. Another orbit was computed by Cunningham from earlier observations, and the elements of both orbits are given below and also an ephemeris. It is approaching the sun and receding from the earth and is not likely to become a spectacular object. At the beginning of March its distances from the sun and earth are 1.8 and 1.07 astronomical units respectively.

$$
\begin{aligned}
& \text { Elements of the ORbit of Comet Timmers. } \\
& \text { Cunningham } \\
& \text { T } 1946 \text {, April 18.820 } \text { U.T. } 1946 \text {, April 14.341 U.T. }
\end{aligned}
$$

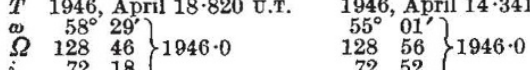

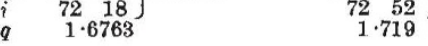

$$
\begin{aligned}
& \text { March } 1946 \\
& \begin{array}{c}
\text { Ephemeris } \\
\text { R.A. } \\
\begin{array}{c}
8 \mathrm{~h} 30 \cdot 3 \mathrm{~m} \\
7 \quad 54 \cdot 9
\end{array}
\end{array} \\
& \begin{array}{l}
\text { Dec. } \\
+67^{\circ} 37^{\prime} \\
71
\end{array}
\end{aligned}
$$

\section{T Coronæ Borealis}

This star is fading rapidly. On February 19 its magnitude was 8 . The earliest observation in Great Britain of the star was made by a boy of fifteen, M. Woodman, 61 Queen's Hill Crescent, Newport, Mon., who reported his observation to the Astronomer Royal. A note on the spectrum of the star, from the Solar Physics Observatory, Cambridge, appears on p. 270 of this issue.

\section{Announcements}

The Committee of Privy Council for the Organisation and Development of Agricultural Research has appointed Mr. Thomas Dalling, director of the Veterinary Laboratory of the Ministry of Agriculture and Fisheries, to be a member of the Agricultural Research Council, in succession to Mr. John Smith, whose term of office has expired.

Dr. N. E. ODELL, president of the Arctic Club and lecturer in geography in the University of Cambridge during 1932-40, is visiting Norway, Sweden and Denmark to lecture by invitation to learned societies, and also under the auspices of the British Council to general audiences, on British achievements in exploration.

THE following appointments have been made in the University of Birmingham: Dr. P. B. Moon, reader in atomic physics in the University, to be assistant professor of physics; Mr. C. H. M. Turner, to be lecturer in electrical engineering; Dr. J. W.
Abbis, to be lecturer in bacteriology; Dr. R. $H$. Bolton, to be full-time medical officer of the University.

The Medal for Merit, highest civilian decoration in the United States of America for war-time service, has been awarded by President Truman to Colonel Sosthenes Behn, president of the International Telephone and Telegraph Corporation, "for exceptionally meritorious conduct in the performance of outstanding services to the United Nations". As president of the International Telephone and Telegraph Corporation, Mr. Behn fostered extensive research and development on radio and telephone equipment; he also visited France and Belgium to re-organise communications laboratories, which enabled the latter to reproduce mobile radio equipment.

Av exhibition to provide an opportunity for trade and research organisations to inspect the facilities of The Metallurgy Division of the Royal Aircraft Establishment will be held in the laboratories at Farnborough during March 5-8 and March 11, from 9.30 a.m. to 4.30 p.m.

The Miners' Welfare Commission invites applications for a limited number of part-time day advanced mining scholarships tenable, as from September next, at approved institutions providing day classes in advanced mining instruction. Candidates for these scholarships must be wage-earning coal mine-workers, at least seventeen years of age on September 1, and have attended an approved part-time senior mining course. Application forms can be obtained from the principals of the mining schools.

Is accordance with its usual practice, Trinity College, Cambridge, announces the offer of a research studentship open to graduates of other universities who propose to go to Cambridge in October next as candidates for the degree of Ph.D. The value of the studentship may be as much as $£ 300$ a year. Candidates must not have reached the age of twenty-six before May 1. The College also offers, as usual, exhibitions of the value of $£ 40$ to students of Dominion and Colonial universities who wish to go to Cambridge next October as candidates for the degree of B.A., M.Litt., M.Sc. or Ph.D. A candidate for a studentship or exhibition should apply through the principal authority of his university, and his application should reach the Senior Tutor, Trinity College, Cambridge (from whom further particulars may be obtained) by May 1.

THE Ministry of Agriculture and Fisheries invites applications for: (1) ten senior scholarships, tenable at university departments of agriculture, agricultural colleges or veterinary colleges, for degree or diploma courses; (2) six extended junior scholarships (for those who have already held junior awards) ; and (3) sixty junior scholarships, tenable at farm institutes or similar institutions. The scholarships are open to the sons and daughters of agricultural workmen and to persons who are themselves bona fide workers in agriculture. The usual method of selection is by interview. Candidates for senior or junior scholarships must have attained the age of seventeen and sixteen years respectively by September 30, 1946. Forms of application (to be returned by April 30) may be obtained from the Secretary of the Ministry, Block 4, Bickenhall Mansions, Baker Street, London, W.1, or from the education offices of county councils. 